\title{
A RARE CAUSE OF DERMAL DEPOSIT
}

Adikrishnan $\mathrm{S}^{1}$, Trishna Vaishali $\mathrm{M}^{2}$, Murugan $\mathrm{S}^{3}$, Mahalakshmi Veeraraghavan ${ }^{4}$, Sudha Rangarajan ${ }^{5}$

\section{HOW TO CITE THIS ARTICLE:}

Adikrishnan S, Trishna Vaishali M, Murugan S, Mahalakshmi Veeraraghavan, Sudha Rangarajan. "A Rare Cause of Dermal Deposit". Journal of Evolution of Medical and Dental Sciences 2015; Vol. 4, Issue 30, April 13; Page: 5241-5245, DOI:10.14260/jemds/2015/767

ABSTRACT: Lipoid proteinosis / Hyalinosis cutis et mucosae is a rare autosomal recessive genodermatosis. Hyaline like material gets deposited in the skin, larynx, oral mucosa, brain.

KEYWORDS: Urbach Wiethe Disease, Autosomal Recessive, Hyaline Deposition.

INTRODUCTION: Lipoid proteinosis / URBACH WIETHE DISEASE is a rare metabolic disease of skin inherited by autosomal recessive pattern. Common among habitants of South Africa. Only about 300 cases have been reported in literature.

CASE REPORT: 17 year old female presented with complaints of progressive hoarseness of voice and waxy scarring of skin over the face since 3 years of age. $\mathrm{H} / \mathrm{O}$ shedding of eyelashes associated with thickening of eyelid margins present since last four years. H/O parental consanguinity present. No $\mathrm{H} / \mathrm{O}$ similar complaints in the family.

ON EXAMINATION: Small papules punctuated by pitted scars (Fig. 2). Lid margins showed typical beading with waxy papules (Fig. 1). Oral mucosa showed yellow plaques (waxy) over buccal mucosa (Fig. 3, 4) The tongue was thickened and patient was unable to protrude fully. Hair, Nails were normal. Systemic examination like cardiovascular, respiratory, CNS, ophthalmologic was normal. On investigation-Videolaryngoscopy showed nodules in the right ventricle and mobile vocal cords. Oral mucosal biopsy - PAS positive hyaline material around capillaries and adnexal structures. IQ assessment showed borderline intelligence. Complete blood count, serum biochemistry, urinalysis were normal. CT brain was normal.

Patient was started on (Oral Retinoids - Isotretinoin) (20mg / 1 day) and asked to come for regular follow up. Patient is undergoing a holistic management along with speech therapy.

DISCUSSION: Hyalinosis cutis et mucosae is a rare autosomal recessive disorder due to mutations in the extracellular matrix protein 1 (EMC 1 ) gene. ${ }^{1}$

Characterized by deposition of hyaline material into skin, oral cavity, larynx, internal organs. Crops of pustules, bullae occur and heals with acneiform pock like scars over the face. (PIG -SKIN LEATHER) appearance. Changes in the larynx leads to hoarseness of voice and may lead to complete aphonia.

The eyelid margins show pearly beaded papules (MONILIFORM BLEPHAROSIS) 2,3,4 Hyperkeratotic, warty, nodular lesions are found on the dorsal aspects of hands, fingers, elbows, knees.

Tongue is "LIKE WOOD" on palpation ${ }^{5}$ and difficulty in protruding the tongue is observed. Intracranial calcifications occur in the hippocampal gyri of temporal lobes. 
Patchy alopecia is seen. HPE Shows hyaline deposition in dermis, around blood vessels and sweat glands. ${ }^{6}$

Skin lesions can be treated with dermabrasion, chemical peeling, Co2 laser therapy. ${ }^{1}$ Oral dimethyl sulphoxide, $\mathrm{d}$ - penicillamine, etretinate have been tired. Microlaryngoscopy can be done for vocal nodules. ${ }^{5}$

\section{REFERENCES:}

1. Black MM. Lipoid proteinosis; Metabolic and nutritional disorders. In: Champion RH, Burton JL, Burns DA, Breathnack SM, eds. Textbook of Dermatology. 8th ed. Oxford, England: Blakcell Science, 2010: 59.41-59.42.

2. Shah MK, Shah PP, Rawal RC, et al Lipoid proteanosis. Indian J Dermatol Venereol Leprol 1996; 62: 375-376.

3. Kaur V, Singh G. Lipoid proteinosis. Indian J Dermatol Venereol Leprol 1992; 58: 399-400.

4. Hamada T, McLean WH, Ramsay M et al. Lipoid proteinosis maps to 1q21 and is caused by mutations in the extracellular matrix protein 1 gene (ECM1). Hum Mol Genet 2002; 11: 833.

5. Dogramaci AC, Celik MM, Celik E, Bayarogullari H. Lipoid proteinosis in the eastern Mediterranean region of Turkey. Indian J Dermatol Venereol Leprol 2012; 78: 318-22.

6. Hougenhouck-Tulleken W, Chan I, Hamada T et al. Clinical and molecular characterization of lipoid proteinosis in Namaqualand, South Africa. Br J Der- matol2004; 151: 413-23.

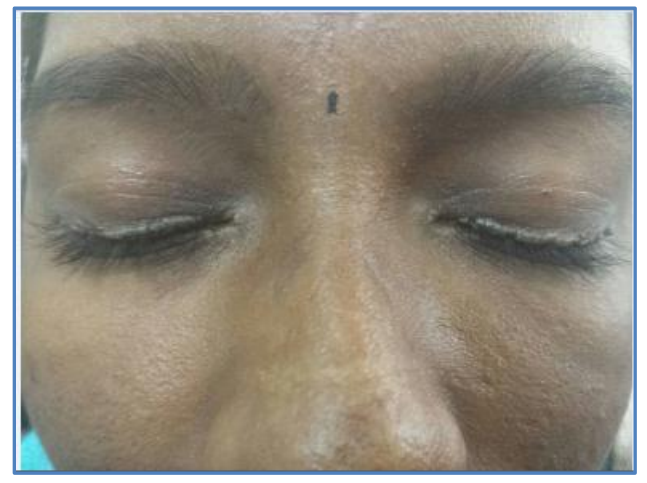

Fig. 1

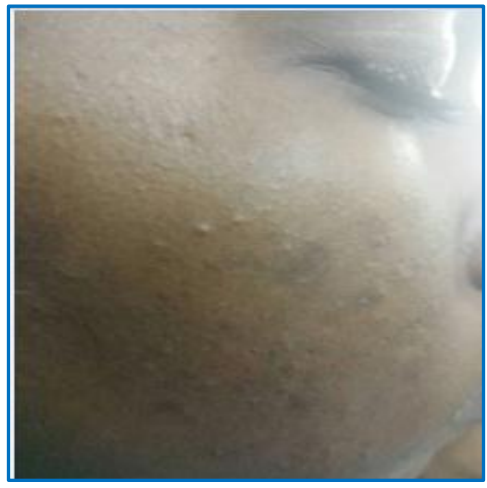

Fig. 2 


\section{CASE REPORT}

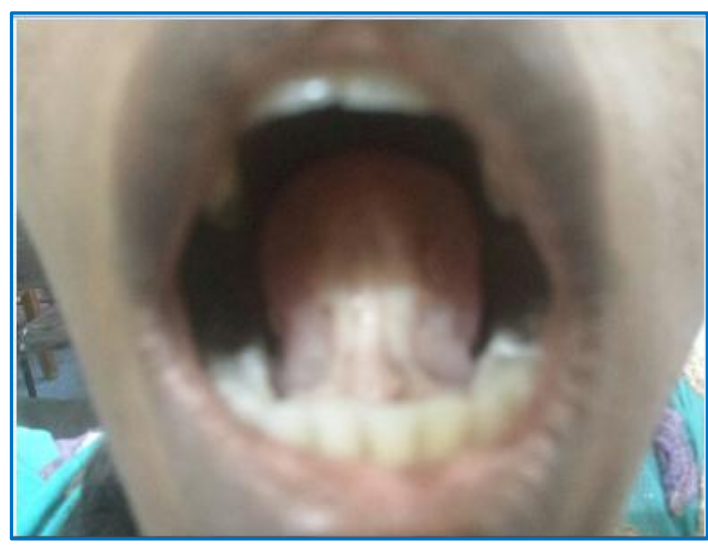

Fig. 3

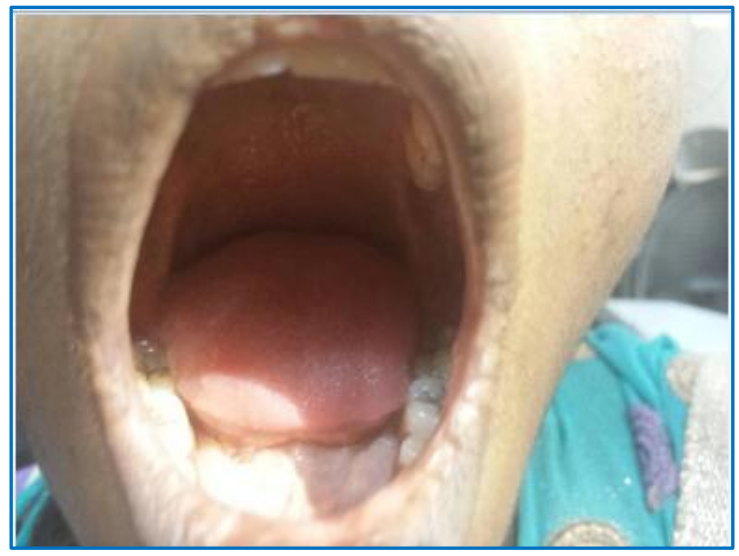

Fig. 4

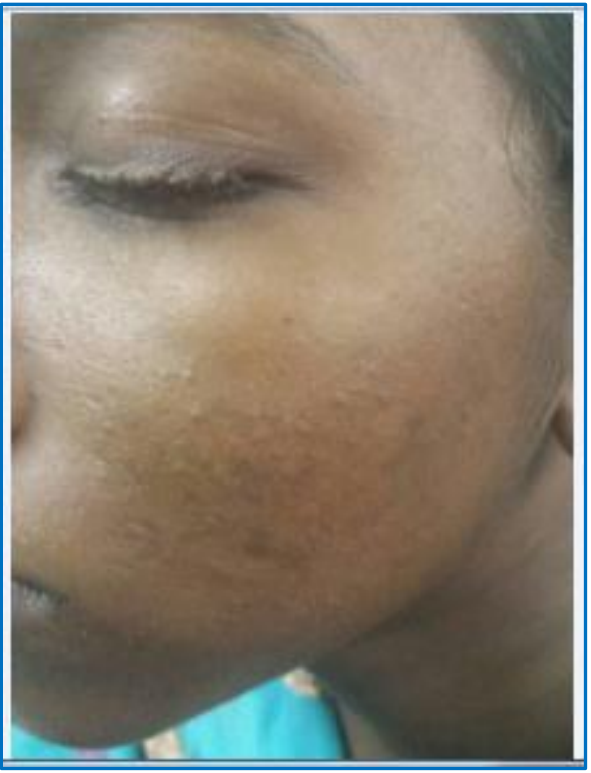

Fig. 5 


\section{CASE REPORT}

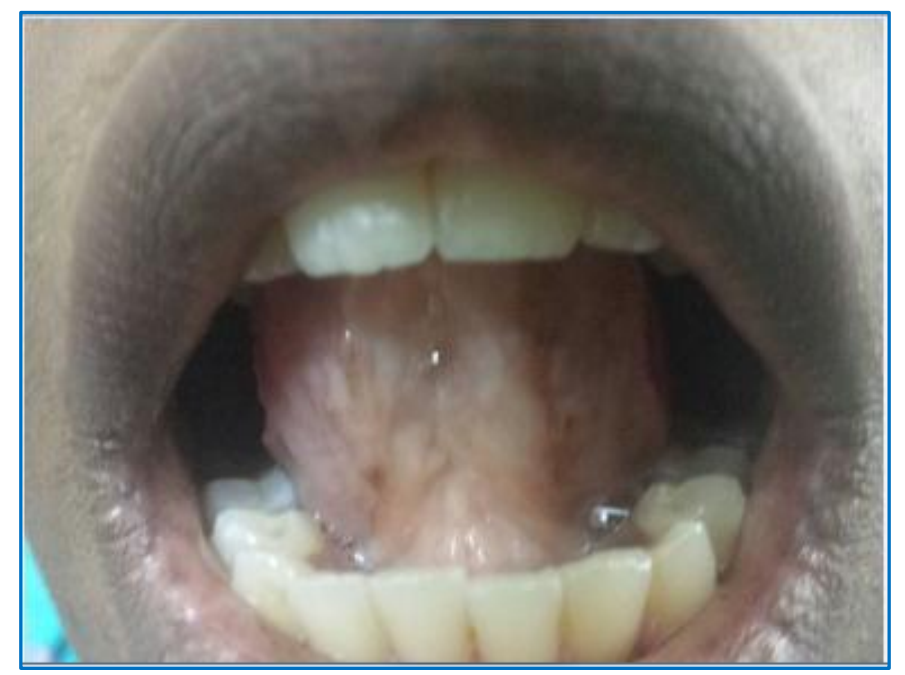

Fig. 6

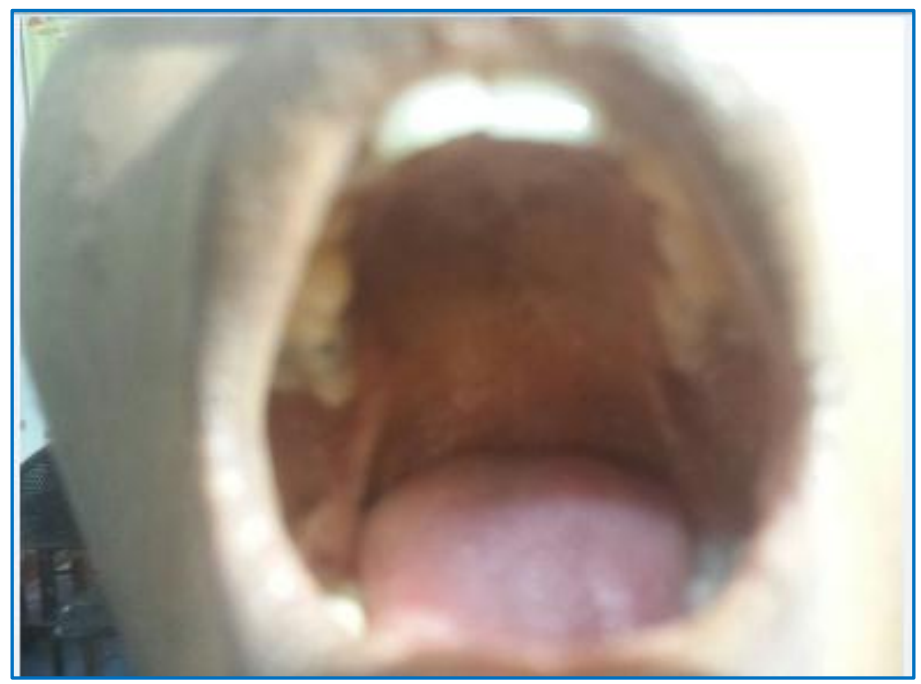

Fig. 7 


\section{CASE REPORT}
AUTHORS:
1. Adikrishnan S.
2. Trishna Vaishali M.
3. Murugan S.
4. Mahalakshmi Veeraraghavan
5. Sudha Rangarajan

\section{PARTICULARS OF CONTRIBUTORS:}

1. Associate Professor, Department of Dermatology, Sri Ramachandra Medical Centre \& Research Institute.

2. Junior Resident, Department of Dermatology, Sri Ramachandra Medical Centre \& Research Institute.

3. Additional Professor, Department of Dermatology, Sri Ramachandra Medical Centre \& Research Institute.

\section{FINANCIAL OR OTHER} COMPETING INTERESTS: None
4. Professor, Department of Dermatology, Sri Ramachandra Medical Centre \& Research Institute.

5. Professor, Department of Dermatology, Sri Ramachandra Medical Centre \& Research Institute.

\section{NAME ADDRESS EMAIL ID OF THE CORRESPONDING AUTHOR:}

Dr. Adikrishnan S, $6^{\text {th }}$ Block-3D, Ceebros Park 2A, Radhakrishnan Salai, Valsarvakkam, Chennai-87.

E-mail:adi_krish@yahoo.com

Date of Submission: 26/02/2015.

Date of Peer Review: 27/02/2015.

Date of Acceptance: 01/04/2015.

Date of Publishing: 13/04/2015. 